依 頼 論 文 《誌上ディベイト フルバランスドオクルージョンかリンガライズドオクルージョンか》

咀嚼時の咬合接触からみた全部床義歯の咬合

鈴木 哲也

\title{
Complete Denture Occlusion Considered from Occlusal Contacts during Mastication
}

\author{
Suzuki Tetsuya
}

\begin{abstract}
抄 録
フルバランスドオクルージョンがリンガライズドオクルージョンよりも機能的に優れていることを示す エビデンスとなる文献はみつけることはできなかった，最近では全部床義歯の咬合様式として，リンガ ライズドオクルージョンにおいてもフルバランスドオクルージョンと同様に, 片側性平衡咬合ではな く, 両側性平衡咬合を与えることが一般的であった。咀嚼時における非咀嚼側の咬合接触は, 咀嚼側よ り早く, 第二大臼歯; 第一大臼歯, 小臼歯の順に起こり, 義歯の転覆を防ぐと同時に, 中心咬合位への 誘導という重要な役割を担っていた。そのため, 咀嚼時においても両側性平衡咬合は義歯の安定に有効 であった．現代の無歯顎者は高齢であり，顎堤の吸収や粘膜の菲薄化がすすみ，顎機能に異常が認めら れる者もいる．下顎位が不安定で，義歯装着後に変化する場合がしばしばある，そのような症例には， 嵌合関係が厳しく規制されるフルバランスドオクルージョンよりも，変化に対応しやすく咬合調整の簡 便なリンガライズドオクルージョンのほうが適している．ただし，日本人の食文化を考えると，咀噜感 賞という点でリンガライズドオクルージョンが適しているかどうかの疑問は残された。咀嚼感覚を評価 する手法の確立が望まれる。
\end{abstract}

和文キーワード

フルバランスドオクルージョン，リンガライズドオクルージョン，両側性平衡咬合，咬合接触，非咀嚼側

東京医科歯科大学大学院医歯学総合研究科摂食機能回復学講座提食機能評価学分野

Complete Denture Prosthodontics, Department of Masticatory Function Rehabilitation, Graduate School, Tokyo Medical and Dental University 


\section{I. はじめに}

歯科医療の進歩と 8020 運動の社会への浸透により, 有床義歯補綴の需要の減少が予想されて久しい.とこ ろが，最近，わが国の高齢者が必要とする有床義歯の 総数は今後 20 年間で 1.5 倍に, 要介護高齢者を対象 にすると今後 25 年間で 1.8 倍に増加するとの将来推 計が報告された ${ }^{11}$.また，同じく先進国である米国に おいても, 今後 20 年間は全部床義歯の需要が増え続 けるであろうとの予測がなされている2). 有床義歯に 関する教育，研究および臨床のますますの充実が不可 欠である.

このような背景をうけ，今回，全部床義歯の咬合様 式としてフルバランスドオクルージョンかリンガライ ズドオクルージョンかの選択をエビデンスに基づき論 じることが求められた。 ところが，フルバランスドオ クルージョンがリンガライズドオクルージョンより優 れていることを示す，エビデンスとなる文献をみつけ ることはできなかった. フルバランスドオクルージョ ンの基となる $\mathrm{Gysi}^{3)}$ の軸学説, 咬合小面学説は, 1929 年という今から 4 分の 3 世紀も前に発表されて いる．この咬合小面学説は, 咬合器と石膏塊と釘から 誕生したもので，義歯の機能，義歯周囲組織の状況な どが十分考慮されていたとは考えにくい.

一方，リンガライズドオクルージョンも Pound ${ }^{4}$ （1970）により命名されてから，早くも 30 年以上が過 ぎている，それ以前の Payne 法5) (1941) や Gerber 法6)（1960）などを含め，広く舌側化咬合を意味する 用語として扱うことは周知とおりである.リンガライ ズドオクルージョンはその理論が広く認められてい る7のにもかかわらず，ほかの咬合様式との優劣など を科学的に検証した論文は，欧米ではほとんどみあた らない.最近ではインプラント義歯に与える咬合とし ての総説,99 が目につくが，全部床義歯を対象とする と，わずかにClough ら ${ }^{10}$ がモノプレーンオクルー ジョンとリンガライズドオクルージョンの義歯の咀嚼 や審美性などを比較し，30 名中の $67 \%$ がリンガライ ズドオクルージョンを好んだとの報告などがみられる 程度である。

一方, 日本では, 松本ら ${ }^{11 \sim 15)}$, 小出ら ${ }^{16 ~ 21)}$ の研究 グループがリンガライズドオクルージョンとフルバラ
ンスドオクルージョンの違いを系統立て検証した論文 を多数発表している. 今回のテーマに直結する原著論 文は両グループのものを除けばあまり多くない222が, 両者とも本ディベイトの執筆者であることから，それ らの研究内容からはできるだけ離れ, 本ディベイトに おいて留意すべき点を整理することから話を進めてみ たい.

\section{II. 何を討論の対象とするのか}

フルバランスドオクルージョンから Gysi そして歯 槽頂間線法則が想起され，また，リンガライズドオク ルージョンから Pound, パウンドラインそして天然 歯が元あった位置への排列へと連想されるように，両 咬合様式の生まれた背景には, 排列法との密接な関係 がある.しかし, 咬合様式の問題を, 歯槽頂間線法則 か，天然歯が元あった位置へ戻すのかといった排列位 置の問題に置き換えて対立軸を立てることは，今回の ディベイトにはそぐわないように思う。歯槽頂間線法 則は義歯の力学的な安定のみを考慮し, その後に進め られた印象面や研磨面に対する解剖学的, 生理学的配 慮 ${ }^{23)}$ がほとんどなされていない時代にできたものであ り, 現在の無歯顎補綴にそのまま適応できるかは疑問 である．歯槽頂間線法則が有する問題点は多数指摘さ れており，排列位置の不正による舌房の侵害などは咬 合様式の違いよりもはるかに大きく義歯の成否にかか わる ${ }^{24)}$. そこで, 咬合様式の違いによる優劣を浮き立 たせるためには，付与する咬合面形態に絞り論じるべ きだと考えた。

次に用語を確認したい.フルバランスドオクルー ジョンという言葉は日本に特有な用語のようで, 欧米 の文献や用語集 ${ }^{25}$ には Balanced occlusion（articulation）という用語は頻出するが, Full balanced occlusion という言葉はなかなかみつからない。と きにみられる Fully balanced occlusion との記述が, 語法だけをとれば正しいように思われる。一般的に咬 合様式のキーワードとなっている Balanced occlusion は Bilateral balanced occlusion と同義語で, 両 側性平衡咬合を意味する ${ }^{25)}$. Full balanced occlusion は両側性平衡咬合の1つであるが Full balanced occlusion をそのまま両側性平衡咬合と訳すことはで きない.この点で用語が曖昧に使われる場合がある。 
全面接触咬合, 全面平衡咬合とか両面均衡接触咬合と いう表現も用いられている. しかし，日本補綴歯科学 会用語集 ${ }^{26)}$ に従い，フルバランスドオクルージョンと するのが最も適切であろう。ちなみに用語集 ${ }^{26)}$ の解説 では,「側方運動時および前方運動時に作業側の歯だ けでなく，前歯も含めた平衡側の歯も円滑に接触滑走 している咬合様式」とある。これには“フル”に込め られた意味合いが，やや欠けるように思われる.

リンガライズドオクルージョンには Payne 法占に代 表される両側性平衡咬合を与える考え方と, Pound 法 ${ }^{4}$ に代表される片側性平衡咬合とする考え方がある とされている．しかし，少なくとも1990 年以降でみ ると, 片側性平衡咬合のリンガライズドオクルージョ ンを推奨する文献はみつけられなかった.リンガライ ズドオクルージョンに扔いても両側性平衡咬合を与え るという考え方 ${ }^{27,28}$ が広く定着してきた感がある。そ うなると, 今回のディベイトは，同じ両側性平衡咬合 内での咬合様式の比較ということになる，従来より， 両側性平衡咬合が全部床義歯の咬合の基本とされてき たが, 最近ではブラキシズムの問題をからめ, 全部床 義歯にも犬歯誘導を与えるべきとの論文 ${ }^{29,30)}$ 発表さ れている，まず，両側性平衡咬合が全部床義歯の咬合 に適しているかどうかを確かめたい.

\section{III. 両側性平衡咬合は咀嚼時においても有効か}

両側性平衡咬合は本当に全部床義歯に与える咬合様 式として有効であろうか. 確かに，義歯に大きな力が 作用していない空口時の義歯の安定には効果が高いと 思われる。しかし, “Enter bolus, exit balanced occlusion”という批判があるように, 両側性平衡 咬合を与えても, 上下咬合面間に食塊が介在する咀嚼 時においては, はたして咬合器上と同じ咬合関係が再 現され，有効なのだろうか. もしそうでなければ，な ぜ，多大な時間と労力をかけて，咬合器上でそのよう な咬合面形態を形作る必要があるのかという疑問が あった。その問いに答えるため，われわれは全部床義 歯の咀嚼時咬合接触を直接的な手法で観察, 記録して きた. 以下に, 当教室で行った一連の研究 ${ }^{31 \sim 38)}$ を順 に紹介し，両側性平衡咬合の有効性を示したい.

小林 ${ }^{31}$ は全部床義歯の臼歯部咬合面を金属に置き換 え, 咀嚼時における咬合接触を電圧の変化により, 直
接的に計測した. Disclusion type の咬合面形態を与 えた場合, 下顎運動に円滑さが欠け，不安定な咬合接 触像（Break of contact）を認めたが, Bilateral balanced occlusion type の咬合面形態を与えた場合に は, 下顎運動は円滑で, 咀嚼時には食塊の厚さだけ離 開しているはずの非咀嚼側のほうが咀嚼側よりも咬合 接触の頻度が高く, その開始も早いことをみいだし た。これらの結果から, 食塊の存在する咀嚼側では義 歯の若干の沈下, 逆に非咀嚼側では浮き上がりという 変位が生じているが, 咬合接触の発現状況や下顎運動 の円滑さから両側性平衡咬合による非咀嚼側の咬合接 触が義歯の安定に寄与していることが推察された。関 田 ${ }^{35)}$ はビデオトラッカーを用いて上顎全部床義歯の動 摇を測定し, 非作業側に咬合接触が生じるゴム片咬み しめ時と非作業側に咬合接触の生じない割箸咬みしめ 時とでは，ゴム片咬みしめ時のほうが動摇量が小さい ことから, 非咀嚼側の咬合接触が義歯の安定に寄与す ることを確認した。

では，この非咀嚼側での咬合接触はどの部位から起 こるのだろうか. 実験義歯に咬合接触検知用発信器を 組み込み, 口腔内テレメータ方式により, 咀嚼時の咬 合接触を観察した ${ }^{33)}$ (図 1). 非咀嚼側での咬合接触 の開始は第二大臼歯, 第一大田歯, 小曰歯の順であ り，接触開始時間の Time lag は第二大臼歯・第一大

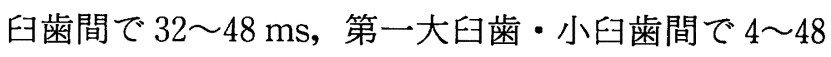
msであった（図 2).この遠心から近心への咬合接触 は, 義歯が沈下, 浮き上がりだけではなく, 食塊を中 心に回転することを示すものである.

渡邊 ${ }^{44)}$ は実験義歯にテレメータ方式の咬合力センサ を組み込み, 人工歯に加わる咬合力の力積の推移を測 定した。咀嚼側では第一大臼歯が最大の荷重および力 積をうけ, 非咀嚼側では咬合接触の開始順序とは逆 に, 第二小臼歯の荷重および力積が最も大きく, 続い て第一大臼歯，第二大臼歯の順であった．非咀嚼側第 二大臼歯から始まる咬合接触は前方へと続き, 各咀嚼 周期のなかで下顎義歯が完全に上顎義歯に咬み込む時 点で，下顎第二小臼歯が衝撃的に上顎人工臼歯と接触 し，上下顎義歯の相対的な動きを止めているのではな いかと推察された. また, 咀嚼の進行に伴い, 咀嚼側 と非咀嚼側の咬合力の力積が均等化していく様相も確 認された。

では, 非咀嚼側の咬合接触は人工歯咬合面上のどこ 


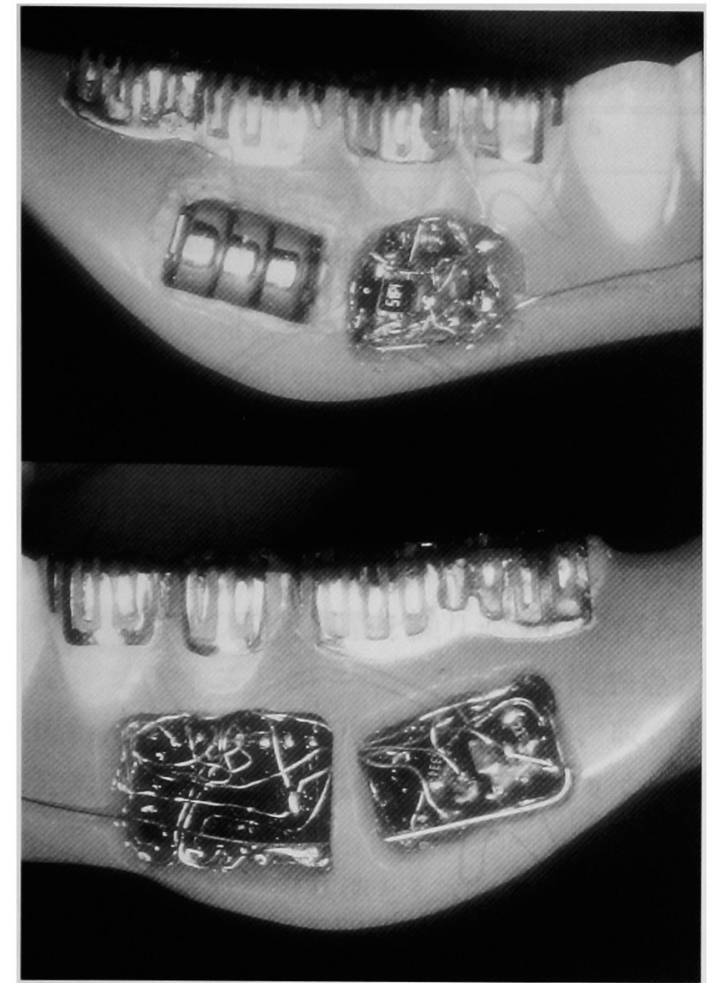

図 1 Experimental lower denture embedded with a telemetry device テレメトリー装置を組み込んだ下顎実験義歯

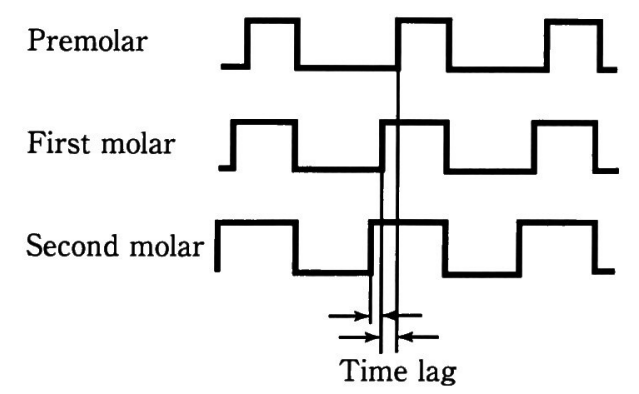

図 2 Order of occurrence of occlusal contacts on the non-chewing side 非咀嚼側における咬合接触開始順序の 模式図

で，どのように生じているのであろうか. 熊谷ら ${ }^{36,37)}$ は咬合接触滑走検知センサを開発し，下顎第一大毛歯 部咬合面に埋め込み, 咀嚼時の咬合接触滑走を計測し た (図 3). 非咀嚼側の咬合接触は, 習慣性咀嚼側で 咀嚼した場合には全ストロークの $36.0 〜 71.1 \%$ が接 触滑走 (excursive closure) を示し, 非習慣性咀嚼 側では 4.9〜20.9\% が接触滑走を示していた（図 4). その接触骬走するストロークのほとんどは“To centric”であった（図 5).“To centric”とは，咀嚼

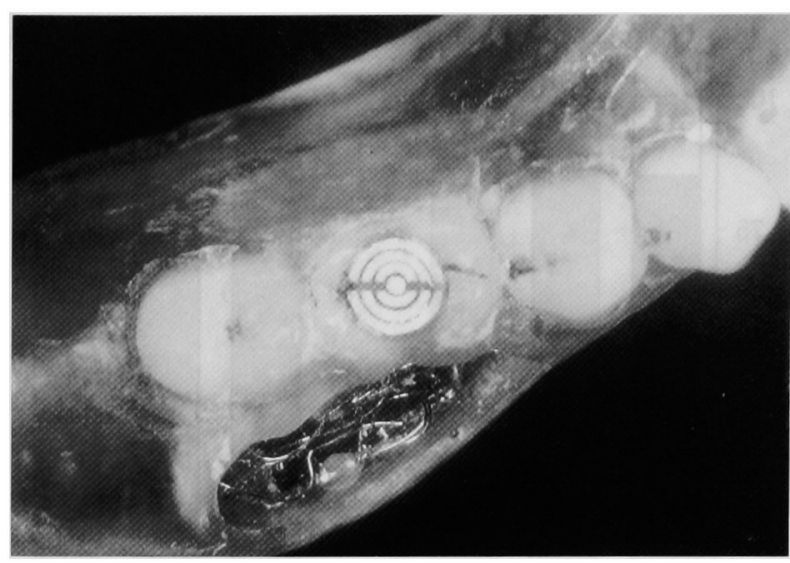

図 3 Experimental lower denture with special switches to measure the occlusal contacts 咬合接触測定用スイッチを組み込んだ下顎実験義歯
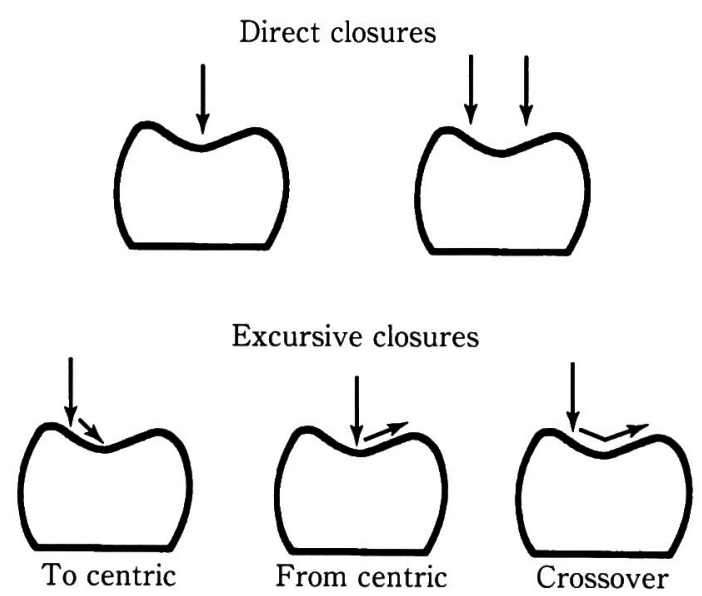

図 4 Classification of the occlusal contacts 咬合接触の分類

側臼歯部咬合面上の食塊による義歯床の回転・変位に より,人工歯内斜面で生じた非咀嚼側での咬合接触 が, 人工歯の咬頭傾斜に誘導されて, 咬頭嵌合位にい たる様子を示している。 また，接触滑走の範囲は，大 部分は咬合面の中心窩から半径 $1.2 \mathrm{~mm}$ であり，それ を超える滑走は咀嚼の初期に認められたのみで，その 滑走範囲も最大半径 $2.2 \mathrm{~mm}$ であった. わずかではあ るが $2.2 \mathrm{~mm}$ 程度の滑走が生じていることは, 人工歯 の固有咬合面の煩舌幅を考えると, 咬頭対咬頭までの 咬合調整の必要性を示唆するものである.

吉富 ${ }^{38)}$ は臼歯部に加え前歯部も交換可能なメタルオ クルーザルとし，前歯部および臼歯部の咬合接触と下 顎運動を記録した. 臼歯部咬合条件を Bilateral balanced occlusion から Non-balanced occlusion へ変 


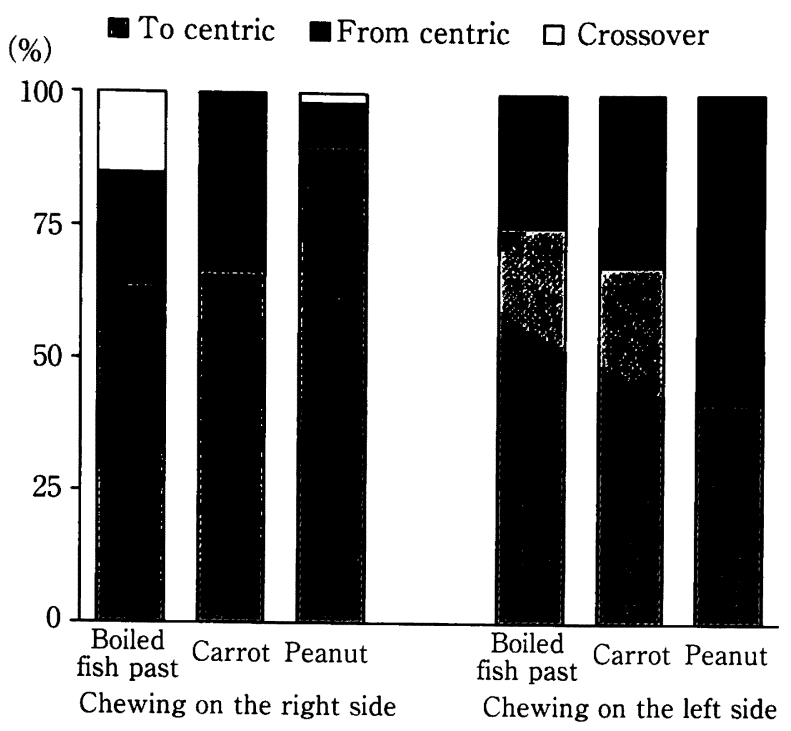

図 5 Incidence of types of excursive closure 接触滑走の分類別頻度

化させると, 閉口相時間の変動係数および中切歯の咬 合接触率が増加すること，また，前歯部の滑走面を削 除すると咀嚼リズムの変動が大きくなることから, 前 歯部の咬合接触も咀嚼運動の安定に寄与していること を明らかにした。

以上の結果をまとめると，全部床義歯は咀嚼時には 咬合器上とは全く異なるダイナミックな様相を示す が, 咬合器上で両側性平衡咬合を与えた義歯での咀嚼 においては，非咀嚼側において咀嚼側より早期に咬合 接触を起こし, 滑走があり，これが義歯のバランスに 貢献していた（図 6)。したがって，両側性平衡咬合 を付与することは，空口時ばかりでなく咀嚼時におい ても有効であることが明かとなった。

\section{IV. 全部床義歯の現状と咬合からみた選択基準}

現代の無歯顎症例像は, Gysi P Pound などのいわ ゆる “Classic article” が対象としていた無歯顎者の 平均的な症例像とは大きく変わっていることが指摘さ れている ${ }^{39)}$. 現代の無歯顎者は高齢であり，何らかの 全身疾患をかかえ, 複数の服用薬を所持している ${ }^{40)}$. 早期に抜歯をすることがなくなったため長く残存歯を 有していた場合が多く，著明な顎堤吸収，菲薄な床下 粘膜，唾液の減少など全部床義歯を製作するのには不 利な条件が多い. さらに, 顎関節に問題がある症例も しばしばみられる，全部床義歯装着者の顎関節症発症
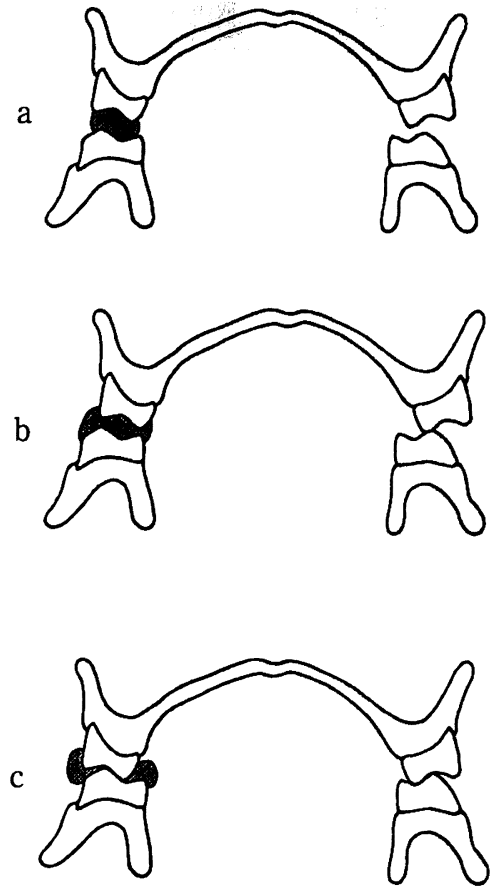

図 6 Illustration of changes of occlusal contacts during mastication 咀嚼時の咬合接触の変化

頻度については Sakurai ら ${ }^{41)}$ の 25\%, Harriman ら ${ }^{42)}$ の $35 \%$ ，そして Hongchen ら ${ }^{43)}$ の $29 \%$ といった 報告がある. 特に田中ら ${ }^{44)}$ は両側顎関節同時撮像 MRIによる観察から，総義歯装着者は顎関節症の主 訴がなくとも顎関節内障を $68.6 \%$, 変形性関節症を $55.7 \%$ に認めたときわめて高い数値を報告している. このような症例にはとりあえず治療用義歯を製作し, 徐々に顎機能の改善を図る必要がある.

使用中の義歯の嵌合位が大きく変位していた場合に は，適応能力に劣る高齢者が新たに設定した嵌合位や 咬合高径にすぐに適応できるかは疑問である．新義歯 装着後の調整期間が十分に確保されなければならな い. 通常の症例でも, 装着後において歯槽骨の吸収や 咬耗により咬合高径や嵌合位が徐々に変化することが 報告されている ${ }^{45)}$. Palla ${ }^{46)}$ はこのような全部床義歯 の咬合の継続的変化や，全部床義歯装着者の閉口路に 一定性が欠けることを理由に, 付与する咬合にはポイ ントセントリックではなく, ロングセントリックゃワ イドセントリックのような自由域を与えるべきだと述 べている.

装着後に大きな咬合の変化が起こるとしたら, 接触 面積が広く嵌合関係が厳しく規制されるフルバランス 
表 1 Mean value $( \pm S D)$ of occlusal contact states in complete denture wearers 全部床義歯装着者の咬合接触状態

\begin{tabular}{lcc}
\hline \hline & Non-adjusted & Adjusted \\
\hline Occlusal force $(\mathrm{N})$ & $147.2 \pm 99.9$ & $276.6 \pm 143.0^{*}$ \\
Mean pressure (MPa) & $44.4 \pm 6.7$ & $43.3 \pm 5.5$ \\
Deviation of center of occlusal loads from median line $(\mathrm{mm})$ & $6.1 \pm 4.1$ & $1.7 \pm 1.3^{*}$ \\
Occlusal contact area $\left(\mathrm{mm}^{2}\right)$ & $3.5 \pm 2.5$ & $6.7 \pm 4.0^{*}$ \\
Occlusal contact points $(\mathrm{n})$ & $8.3 \pm 4.4$ & $15.2 \pm 6.0^{*}$ \\
\hline & ${ }^{*}: \mathrm{p}<0.01, \quad(\mathrm{n}=100)$
\end{tabular}

ドオクルージョンでは，ただちには対応することは難 しい47).チェックバイト，リマウントという作業の 後, 咬合器上での咬合調整を繰り返す必要がある。一 方，リンガライズドオクルージョンは接触点が少な く，嵌合位における自由度が大きいため，咬合関係の 変化に対応しやすい， 口腔内だけの調整ですむ場合も 多い.

そこで, 第一の選択基準として, 咬合の安定性を挙 げたい. 嵌合位が不安定で義歯装着後の変化が予想さ れる場合には，リンガライズドオクルージョンが適し ており，また，その適応症は比較的多いと思われる。

第二の選択基準として, 術者の技量を挙げたい. 咬 合採得が正確に行え，術者が望む咬合様式を理解し， 的確に咬合面上に形成できる能力があるかということ である．表 1 は使用中の義歯における中心咬合位での 最大嚙みしめ時の咬合接触状態である ${ }^{48)}$. 咬合力の重 心が大きく正中線からずれており，中心咬合位におい てさえ咬合調整がままならない義歯および術者が多数 存在することを示している．このような場合，まずは 理解しやすく，技術的にも習得しやすい咬合様式を選 び，義歯に付与することが大切であろう ${ }^{47) . ~ リ ン カ ゙ ラ ~}$ イズドオクルージョンは左右側 5 点ずつの咬合接触点 の動きを追うだけなので分かりやすいが，フルバラン スドオクルージョンは多数の咬合小面で構成されるた め，その理論を理解し，咬合面上に再現することはな かなか難しく，習熟に時間を要する，咬合採得の多少 の誤りでも修正しやすいという点ではリンガライズド オクルージョンは適している.

では，下顎位も比較的安定しており，十分な臨床技 術も有していたら，どちらを選択すべきであろうか.

\section{V. フルバランスドオクルージョンは何が 優れているのか}

リンガライズドオクルージョンへの根強い批判とし ては, リンガライズドオクルージョンは咀嚼能率が劣 ること, 食塊の流れが頓側に向かうこと, 食べ物を咬 んでいる感じがしないことなどがあげられ，そもそも 日本人の食生活にあっていないとの意見 ${ }^{49}$ も聞かれ る.

確かに，舌側に落ちるべき食塊の流れが煩側に向か うことは，煩への食渣の侵入を招きやすく，それを防 ごうとする煩筋の負担を強め, 咀嚼時の円滑な煩舌の 協調という点では不利と思われる。また，咀嚼能率に 関しては，咬合接触面積の広いフルバランスドオク ルージョンが当然有利である，ところが，硬性食品で は，リンガライズドオクルージョンが勝っていたとの 報告 ${ }^{15)}$ もり，咀嚼能率や食塊の流れがフルバランス ドオクルージョンを強く支持する理由には成り得ない と思う。

では，時折耳にする「リンガライズドオクルージョ ンでは食べ物を咬んでいる感じがしない」という批判 は本当なのであろうか.「食べやすさ」と「美味しさ」 は必ずしも一致しないといわれている。フルバランス ドオクルージョンとリンガライズドオクルージョンの 咀嚼の違いは，単純化すれば，上下顎人工歯煩側咬頭 どうしでの咬合接触，臼磨運動が行われるか否かの違 いである．煩側咬頭どうしでの咬合接触は義歯の安定 を損ない，咬合接触のない場合に比べ顎堤に大きな負 担がかかると報告されている。しかし，歯根膜という 鋭敏な感覚受容器を衰失し，感覚の劣る粘膜や顎関 節，筋紡鍾などの受容器に感覚を委ねている無歯顎 者年にはは，むしろ好ましい抵抗感として感じられる症 
例もあるように思われる。頪側咬頭どうしが臼磨運動 に積極的に参加するフルバランスドオクルージョンは ダイナミックな咀嚼運動が展開され, 美味しさを生み 出すのかもしれない.

大山年は「日本の食文化は『歯ごたえ』，『歯ざわ り』を大切にする．欧米の食文化とは異なる」と述べ ており，五十嵐ら ${ }^{52)}$ はわれわれが日常拝見している 現在の高齢患者では，義歯により米飯などの食品を上 下䫟咬合面間で圧迫し，その感触で「旨い」という感 覚を得ている個体が多いようである」との感想を述べ ている.「旨い」という咀嚼感覚をどのように科学的 に検証するかが残された問題かと考える.

\section{文献}

1）金谷 貢，渡辺孝一，宮川 修．高龄者および要援護高 齢者にかかわるブリッジ数と有床義歯数の将来推計の試 み. 補緅誌 45：227-237, 2001.

2) Douglass CW, Shih A, Ostry L. Will there be a need for complete dentures in the United States in 2020? J Prosthet Dent 87:5-8, 2002.

3) Gysi A. Pratical application of research results in denture construction. J Am Dent Assoc 16:199-223, 1929.

4) Pound E. Utilizing speech to simlplify a personalized denture service. J Prosth Dent 24 : 586-600, 1970.

5) Payne SH. A Posterior set-up to meet individual requirements. Dental Digest $47: 20-22,1941$.

6) Gerber A, Steinhardt G. Carmichale RP. Dental occlusion and the temporomandibular joint 24-25. Chicago: Quintessence, 1990.

7) Parr GR, Ivanhoe JR. Lingualized occlusion. An occlusion for all reasons. Dent Clin North Am 40 : 103-112, 1996.

8) Reitz JV. Lingualized occlusion in implant dentistry. Quintessence Int 25:177-180, 1994.

9) Khamis MM, Zaki HS, Rudy TE. A comparison of the effect of different occlusal forms in mandibular implant overdentures. J Prosthet Dent 79:422-429, 1998.

10) Clough HE, Knodle JM, Leeper SH et al. A comparison of lingualized occlusion and monoplane occlusion in complete dentures. J Prosthet Dent $50: 176-179$, 1983.

11）井上三四郎，河野文昭，永尾 寛ほか. 全部床義歯床下 組織の負担圧分布に関する基礎研究 第 3 報 $⿴ \zh11$ 歯人工 歯の咬合面形態の差が負担圧分布に及ぼす影響. 補綴誌 39 : 501-510, 1995.
12）松本直之，永尾 寛，河野文昭．全部床義歯床下組織の 負担圧分布に関する基礎研究 第 4 報 咬合様式の差が 義歯下組織の負担圧分布に及ほす影響. 補経誌 41 ： 44-51, 1997.

13）松本直之，河野文昭，永尾 寛ほか. 臼歯部人工歯の選 択についてーシミュレーションモデルによる検討一. 補 綴誌 $41 ： 335-346,1997$.

14) Ohguri $T$, Kawano $F$, Ichikawa et al. Influence of occlusal scheme on the pressure distribution under a complete denture. Int $\mathrm{J}$ Prosthodont $12: 353-358$, 1999.

15）大栗孝文，河野文昭，市川哲雄ほか. 顂側咬頭間隙量が 負担圧分布に及ぼす影響一シミュレータによる検討一。 補緅誌 $44: 394-403,2000$.

16）小出 馨. 総義歯の咬合接触様式に関する実験的研究. 歯学 $72: 231-265,1984$.

17）樋口昌男，旗手 敏. 有床義歯に付与する咬合接触様式 の相違が食品破砕効果に及ぼす影響一リンガライズド・ オクルージョンとフルバランスド・オクルージョンの比 較. 歯学 $83 ： 225-247,1995$.

18）五味㴊泰造, 小出 馨, 旗手 敏. リンガライズド・オ クルージョンとフルバランスド・オクルージョンの咀嚼 機能について。補綴誌 $44: 339-347,2000$.

19）田村隆英，佐藤利英，小出 馨. リンガライズド・オク ルージョンにおける滑走間隙量の変化が食品破砕に及ほ す影響. 補緅誌 $45: 67-79,2001$

20）鶴巻富貴子, 小出 馨, 佐藤利英. リンガライズ・オク ルージョンとフルバランスド・オクルージョンの食品破 砕力積. 補綴誌 $45: 80-92,2001$.

21）菅原佳広, 小出 䣨, 佐藤利英. リンガライズド・オク ルージョンにおける滑走間隙量が咀嚼機能に及ぼす影 響. 補緅誌 $46 ： 357-366,2002$.

22) Ohnuki M, Nishiyama $Y$, Hosoi $T$ et al. Functional efficacy of full balanced occlusion and lingualized occlusion evaluated from morphological differences in edentulous alveolar ridge. Prosthodont Res Pract 1: 31-40, 2002

23) Watt DM, MacGregor AR. Designing complete dentures, 2 nd ed.1-88, Bristol : Wright, 1986.

24）早川䉷.コンプリートデンチャーの理論と臨床 56-95, 東京：クインテッセンス出版, 1995.

25) The Academy of Prosthodontics. The glossary of prosthodontic terms, 7 th ed. J Prosthet Dent 81 : 41-110. 1999.

26）日本補綴歯科学会編. 日本補綴歯科学会用語集 61-62, 東京：医歯薬出版, 2001.

27）小出警. リンガライズド・オクルージョン. 歯科 ジャーナル $32: 627-642,1990$.

28）松本直之：リンガライズドオクルージョンの実際 8-79, 東京：デンタルダイヤモンド社, 1993.

29) Miralles R, Bull R, Manns A et al. Influence of bal- 
anced occlusion and canine guidance on electromyographic activity of elevator muscles in complete denture wearers. J Prosthet Dent $61: 494-498,1989$.

30) Peroz I, Leuenberg A, Haustein I, Lange KP. Comparison between balanced occlusion and canine guidance in complete denture wearers - a clinical, randomized trial. Quintessence Int 34:607-612, 2003.

31）小林賢一．全部床義歯の咀緭時における咬合接触の動態 一特に, 非咀嚼側について一。補綴誌 $27: 150-167$, 1983.

32）守澤正幸． 全部床義歯の咀嚼時における咬合接触． 口病 誌 $53: 255-280,1986$.

33）小林賢一, 守澤正幸, 渡邊竜登美ほか。テレメータリン グによる全部床義歯の咬合接触. 補緅誌 $33: 94-105$, 1989.

34）渡邊竜登美. 全部床義歯咀嚼時咬合力に関する研究. 病誌 $57: 16-31,1990$.

35）関田俊明. 上罰全部床義歯の咬合時の動摇に関する研 究. 補経誌 $35: 137-150,1991$.

36）熊谷 宏. 全部床義歯装着者の咀翾運動に関する臨床的 研究一咀嚼運動経路と咬合接触について一。病誌 $60: 15-34,1993$.

37) Kumagai $\mathrm{H}$, Watanabe $\mathrm{T}$, Kobayashi $\mathrm{K}$ et al. Incidence of occlusal contacts with complete dentures during mastication using a 6 -channel telemetry system : Preliminary measurements. J Oral Rehabil 26 : 918-922, 1999.

38）吉富信幸. 咀嚼時における全部床義歯前歯部咬合接触が 下顎運動に及ほす影響。口病誌 64：436-453, 1997.

39) Ivanhoe JR, Cibirka RM, Parr GR. Treating the modern complete denture patient: A review of the literature. J Prosthet Dent 88:631-635, 2002.

40）海野雅浩, 佐藤顕正, 渡邊竜登美ほか，高齢歯科患者の 全身疾患の合併状況一東京医科歯科大学高齢者歯科治療 部に打ける調查一。老年歯科医学 6:26-349, 1991.

41) Sakurai K, Giacomo TS, Arbree NS et al. A survey of temporomandibular joint dysfunction in completely edentulous patients. J Prosthet Dent 59:81-85, 1988.

42) Harriman LP, Snowdon DA, Messer LB et al. Temporomandibular joint dysfunction and selected health pararmters in the elderly. Oral Surg Oral Med Oral Pathol 70: 406-413, 1990.

43) Hongchen L, Ning L, Jilin $Z$. Characteristics of temporomandibular joint disorder in edentulous patients. Orofacial Pain 8: 104, 1994.

44）田中久敏, 虫本栄子, 千葉雅之ほか. 総義歯装着者にお ける顎関節症の臨床的特徴一顎関節内障の発生頻度一。 補経誌 39：396-405, 1995.

45) Utz KH. Studies of changes in occlusion after the insertion of complete dentures (part II). J Oral Rehabil $24: 376-384,1997$.

46) Palla S. Occlusal considerations in complete dentures. In : Mcneill C, editor, Science and practice of occlusion 457-467, Hong Kong: Quintessence, 1997.

47）松本直之，河野文昭. コンプリートデンチャーに与える 人工歯の咬合様式とその選択. 歯科ジャーナル 32 ： 657-667, 1990.

48) Suzuki $T$, Kumagai $H$, Watanabe $T$ et al. Evaluation of complete denture occlusal contacts using pressuresensitive sheets. Int J Prosthodont 10:386-391, 1997.

49）河邊清治, 村岡秀明. 生体機能に調和を求めて. 補綴臨 床編集部編，総義歯臨床のポイントを探る一河邊清治・ 山本為之・横田 亮先生に聞く- 4-38, 東京: 医歯薬出 版, 1992.

50）小林章二．全部床義歯装着者における顎運動の負荷なら びに脱負荷に対する短潜時応答. 口病誌 $61: 56-70$, 1994.

51）大山喬史．歯は道具でなくすばらしい感覚器である一日 本の食文化からの一考察一。日顎誌 $8: 227-228.1995$.

52）五十嵐順正，山下秀一郎，藤牧伸成ほ力，傊歯列にお ける咬合支持と短縮歯列の考え一その運用と限界一. 補 綴誌 47：721-735, 2003.

著者連絡先：鈴木 哲也

干113-8549 東京都文京区湯島 1-5-45

TEL : 03-5803-5583

FAX : 03-5803-0214

E-mail : t.suzuki.ore@tmd.ac.jp 


\title{
Complete Denture Occlusion Considered from Occlusal Contacts during Mastication
}

\author{
Suzuki Tetsuya \\ Complete Denture Prosthodontics, Department of Masticatory Function Rehabilitation, \\ Graduate School, Tokyo Medical and Dental University
}

J Jpn Prosthodont Soc $47: 664-672,2003$

\begin{abstract}
Few reports describe the functional superiority of full balanced occlusion to that of lingualized occlusion. Recently, a bilateral balanced scheme has been much more generally applied than a unilateral balanced scheme in lingualized occlusion as well as in full balanced occlusion. Occlusal contacts on the non-chewing side occur earlier than on the chewing side ; in the order of second molar, first molar, and then premolars. The contact on the balancing side contributes to the prevention of denture dislocation and guidance from eccentric positions to the centric occlusal position during mastication. Therefore, bilateral balanced occlusion was shown to be effective for denture stability during mastication with complete dentures. Today's typical edentulous patients have greater mean age than in the past, and thus are seen with severe alveolar bone resorption, thin mucosa and sometimes abnormalities of the maxillomandibular relation. Their occlusal positions are often unstable and changeable after insertion of complete dentures. Because lingualized occlusion allows for easier accommodation and correction, lingualized occlusion is more suitable for such cases than full balanced occlusion, which requires a strict occlusal relationship. In light of the standard Japanese diet, there is some doubt about why lingualized occlusion might be suitable for Japanese edentulous patients in terms of the sense of mastication. A method of evaluating the sense of mastication needs to be established.
\end{abstract}

\section{Key words}

full balanced occlusion, lingualized occlusion, bilateral balanced occlusion, Occlusal contact, nonchewing side 